\title{
Penggunaan Video Pembelajaran Berbasis Aplikasi Bandicam pada Mata Kuliah Teori Graf Untuk Meningkatkan Kemampuan Abstraksi Mahasiswa
}

\author{
Heri Cahyono \\ Program Studi Pendidikan Matematika, STKIP Modern Ngawi \\ Email: hericahyono@live.com
}

\begin{abstract}
Abstrak
Tujuan dari penelitian ini adalah untuk mengetahui keefektifan penggunaan video pembelajaran berbasis aplikasi bandicam pada pembelajaran daring pada mata kuliah teori graf. Metode yang digunakan dalam penelitian ini adalah metode eksperimen, yaitu dengan mengambil dua kelompok yang dijadikan sampel penelitian. Kelompok pertama diberikan pembelajaran dengan pembelajaran daring yang diberikan video yang bebasis aplikasi bandicam, dan kelompok yang kedua diberikan pembelajaran daring tanpa menggunakan video pembelajaran berbasis aplikasi bandicam pada mata kuliah teori graf. Penelitian ini dilakukan di STKIP Modern Ngawi Kecamatan Ngawi Kabupaten Ngawi dengan jumlah sampel 18 mahasiswa, dengan pembagian 9 mahasiswa sebagai kelas eksperimen dan 9 mahasiswa sebagai kelas control. Uji yang digunakan pada penelitian ini adalah uji-t dengan uji prasyarat uji nomalitas dan homogenitas pada kedua kelompok sampel. Hasil penelitian ini adalah rata-rata kelas eksperimen 85,35 dan kelas kontrol 64,80. Berdasarkan hasil uji hipotesis dengan uji-t dan $\alpha=5 \%$ diperoleh $t_{\text {obs }}=1,187$ dan $t_{\text {tabel }}=$ 1,645 sehingga $D K=\{t \mid t<-1,960$ atau $t>1,960\}$. Simpulan uji hipotesis adalah H0 ditolak maka kesimpulannya, kemampuan abstraksi mahasiswa pada mata kuliah teori graf menggunakan video pembelajaran berbasis aplikasi bandicam lebih baik daripada pembelajaran daring tanpa video pembelajaran berbasis aplikasi bandicam.
\end{abstract}

Kata Kunci: abstraksi, video, pembelajaran, bandicam, teori graf

\section{PENDAHULUAN}

Semakin pesatnya penggunaan sistem informasi dan komputer di era global, mengharuskan pembelajaran di perguruan tinggi mengikuti perkembangan tersebut. Pentingnya penggunaan perkembangan teknologi dalam pendidikan harus disadari oleh semua pihak terutama oleh dosen dan mahasiswa di semua perguruan tinggi utamanya dimasa pandemi. Sayangnya, tidak semua lembaga pendidikan mampun menerapkan serta mengikuti perkembangan teknologi yang berbasis komputer secara maksimal.

Banyak faktor yang mendasari mengapa belum optimalnya penerapan teknologi komputer dalam pendidikan diantaranya masalah sarana dan prasarana, kemampuan pangajar dalam mengoperasikan komputer/aplikasi, bahkan motivasi pengajar yang kurang dalam melakukan mengembangkan model pembelajaran. Beberapa faktor tersebut menyebabkan kurangnya pemahaman mahasiswa pada materi tertentu yang berimbas pada rendahnya nilai mahasiswa. Dari keseluruhan mata kuliah di pendidikan matematika terdapat beberapa mata kuliah yang sebagian besar nilai mahasiswa dibawah nilai kelulusan, dari hal tersebut sudah sepatutnya dosen melalukan evaluasi terhadap proses belajar mengajar baik itu pada teknik yang digunakan dalam mengajar maupun pengembangan media serta model pembelajaran yang digunakan. Matematika merupakan suatu kebutuhan bagi setiap orang saat ini, perkembangan teknologi dan semakin pentingnya sarana komunikasi dan komputer membuat orang perlu untuk beradaptasi dengan situasi baru untuk melakukan perubahan (Ignacio, 2006: 16).

Pada mata kuliah teori graf banyak membahas objek-objek berupa titik dan garis, dan lebih lanjut graf akan membentuk 
menyerupai bangun atau diagram tertentu yang semakin banyak titik dan garisnya akan semakin rumit. Semua objek-objek dari bangun merupakan benda abstrak yang hanya ada dalam pikiran (Iswaji, 2001:1).

Pada proses pembelajaran secara daring sering sekali dosen menggunakan aplikasi elearning dengan berbagai platform, meskipun demikian tidak bisa dipungkiri bahwa sebagian besar dari platform e-learning tersebut berupa teks perintah-perintah dan membagian materi perkuliahan. Dalam kenyataannya mahasiswa harus mampu mengabastraksi bentuk-bentuk gambar ke dalam konsep matematika.

Dalam konteks pendidikan matematika mengabstraksi dapat diartikan sebagai suatu proses mempelajari ide-ide, objek-objek atau konsep-konsep yang bersifat abstrak. Konsepkonsep yang abstrak dalam matematika tersebut dapat dipelajari melalui proses abstraksi empiris maupun melalui abstraksi matematis (beberapa ahli ada yang menyebutnya sebagai abstraksi reflektif atau abstraksi teoretis). Proses abstraksi tersebut berlangsung melalui serangkaian aktivitas pembelajaran yang melibatkan berbagai aspek pembelajaran. Salah satu aspek yang cukup penting dalam proses pembelajaran matematika adalah alat peraga (Nurhasanah: 2009).

Di era saat ini sangat banyak programprogram komputer yang tersedia yang dapat digunakan untuk membuat video pembelajaran, salah satunya adalah aplikasi berbasis perekam layar yaitu bandicam. Bandicam bisa dibilang sangat cocok untuk digunakan dalam kombinasi dalam pembelajaran daring, terutama jika diintegrasikan dengan platform e-learning. Dengan aplikasi bandicam pengajar dapat memberikan penjelasan langsung berupa tangkapan layar dan disertai dengan berbagai menu lainnya yang dapat mendukung proses pembelajaran.

Menurut Hamdan Husein (2020) manfaat video pembelajaran dibagi menjadi 2 yaitu manfaat bagi siswa dan manfaat bagi pendidik. Manfaat video pembelajaran bagi siswa adalah meningkatkan motivasi belajar siswa; meningkatkan pemahaman siswa; meningkatkan keterlibatan siswa dalam proses pembelajaran; meningkatkan kemandirian siswa dalam belajar. Manfaat video pembelajaran bagi pendidik adalah melatih kreatifitas pendidik; meningkatkan jumlah hak cipta pendidik (HKI); meningkatkan personal branding pendidik; meningkatkan penghasilan.

Adapun proses abstraksi menurut Wiryanto (2014:573) sebagai berikut: 1) mengidentifikasi karakteristik objek melalui pengalaman langsung, 2) mengidentifikasi objek/mengimajinasikan, 3) membuat generalisasi, 4) mempresentasikan gagasan, 5) melakukan idealisasi, 6) membuat hubungan proses dan pengertian baru, 7) mengaplikasikan konsep, 8) manipulasi objek matematik yang abstrak. Dari teori diatas untuk mampu mengabstraksikan suatu keadaan ke dalam pikiran maka seluruh tahapan abstraksi harus dilampui, pada tahapan ke dua yaitu "mengidentifikasi objek/mengimajinasikan" harus dilalui dengan sempurna. Kemampuan mengimajinasi setiap mahasiswa berbeda-beda sehingga dengan menambahkan media pembelajaran yang membantu memudahkan proses mengimajinasi merupakan cara yang tepat untuk memperbaiki kekurangan tersebut.

Hasil penelitian yang dilakukan oleh Tosin (2013:94) menyatakan bahwa rata-rata siswa mempunyai prestasi belajar rendah dan kesulitan dalam memahami geometri dimensi tiga. Dalam hal ini penggunaan video pembelajaran dirasa tepat untuk mengajarkan materi-materi yang menuntut pengetahuan deklaratif dan pengetahuan prosedural, apalagi dalam pembelajaran matematika kedua pengetahuan tersebut sangat diperlukan untuk memahami materi matematika di perguruan tinggi. Berdasarkan uraian tersebut maka dianggap perlu adanya modifikasi pembelajaran daring 
dengan menambahkan penjelasan berupa video pembelajaran didalamnya.

Pembelajaran pada setiap siswa pada dasarnya adalah bersifat individual karena setiap siswa belajar melalui tahapan-tahapannya masing-masing.

\section{METODE}

Jenis penelitian yang digunakan adalah penelitian eksperimen. Penelitian ini dilaksanakan di STKIP Modern Ngawi. Pemilihan lokasi penelitian didasarkan pada kondisi kecukupan materi dan tersedianya Program Studi Pendidikan Matematika di STKIP Modern Ngawi. Populasi penelitian ini adalah seluruh mahasiswa Program Studi Pendidikan Matematika semester 7 di STKIP modern Ngawi 2020/2021. Teknik pengambilan sampel dengan menggunakan Cluster random sampling, yaitu dengan cara mengambil secara acak 2 kelompok dari kelas yang ada, sehingga ditetapkan Kelompok B sebagai kelas kontrol dengan jumlah 9 mahasiswa dan Kelompok A ditetapkan sebagai kelas eksperimen dengan jumlah 9 mahasiswa.

Variabel dalam penelitian ini adalah variabel bebas dan variabel terikat, variabel bebas dalam penelitian ini adalah pembelajaran daring sedangkan variabel terikatnya adalah kemampuan abastraksi mahasiswa. Metode pengumpulan data yang digunakan adalah metode tes dan metode dokumentasi. Metode tes digunakan untuk memperoleh data ujian mahasiswa yang memuat abstraksi matematika, sedangkan metode dokumentasi digunakan untuk mendapatkan data-data sampel penelitian dan data kemampuan awal mahasiswa sebelum dilakukan penelitian.

Instrumen yang digunakan dalam penelitian ini berupa rencana pelaksanaan pembelajaran secara daring yang didalam sintaknya telah dimodifikasi menggunakan video pembelajaran berbasis aplikasi bandicam. Data kemampuan awal mahasiswa diperoleh dari data ujian akhir semester ganjil tahun pelajaran 2019/2020. Selanjutnya untuk memperoleh data nilai mahasiswa digunakan soal tes uji kemampuan yang sebelumnya telah diuji validitas dan reliabilitasnya.

Prosedur analisis data pada penelitian ini adalah melakukan uji keseimbangan terlebih dahulu data kemampuan awal pada kelas eksperimen dan kelas kontrol. Uji keseimbangan menggunakan uji-t dengan prasyarat normal dan homogen. Selanjutnya data tes prestasi siswa (postes) diuji normalitas dan homogenitasnya, selanjutnya dilakukan pengujian hipotesis dengan menggunakan uji-t.

Rancangan penelitian yang digunakan dalam penelitian ini digambarkan pada tabel berikut:

Tabel 1. Desain Penelitian

\begin{tabular}{|l|c|c|c|}
\hline \multicolumn{1}{|c|}{ Kelompok } & Kondisi Awal & Perlakuan & Postes \\
\hline $\begin{array}{l}\text { Eksperimen } \\
\text { (A) }\end{array}$ & $\mathrm{Q}$ & $\mathrm{X}_{1}$ & $\mathrm{~T}$ \\
\hline Kontrol (B) & $\mathrm{Q}$ & $\mathrm{X}_{2}$ & $\mathrm{~T}$ \\
\hline
\end{tabular}

Kelas dengan kondisi awal yang seimbang (Q) dibagi menjadi 2 kelompok yaitu sebagai kelompok A sebagai kelas eksperimen dan kelompok B sebagai kelas kontrol, selanjutnya dikenakan perlakuan pembelajaran daring dengan memberikan video pembelajaran berbasis aplikasi Bandicam $\left(\mathrm{X}_{1}\right)$ pada kelompok eksperimen dan pembelajaran daring tanpa video pembelajaran $\left(\mathrm{X}_{2}\right)$ pada kelas kontrol. Kedua kelas pada tahap akhir diberikan soal tes terkait materi pada mata kuliah teori graf yang selanjutnya dianalisis sebagai hasil penelitian.

\section{HASIL DAN PEMBAHASAN}

Uji yang pertama dilakukan adalah uji prasyarat keseimbangan, yaitu uji normalitas dan homogenitas yang dilakukan pada data kemampuan awal siswa. Rangkuman uji normalitas dengan uji Lilliefors dengan taraf signifikansi $\alpha=5 \%$ sebagai prasyarat uji keseimbangan disajikan pada tabel berikut. 
Tabel 2. Rangkuman Uji Normalitas

\begin{tabular}{|c|c|c|c|c|}
\hline Kelas & $N$ & $\begin{array}{c}L=M a k s \mid F\left(z_{\mathrm{i}}\right)- \\
S\left(z_{\mathrm{i}}\right) \mid\end{array}$ & Kep. Uji \\
\hline Eks. & 9 & 0,1568 & 0,1618 & $\mathrm{H}_{0}$ diterima \\
\hline Kontrol & 9 & 0,1512 & 0,1591 & $\mathrm{H}_{0}$ diterima \\
\hline
\end{tabular}

Dari tabel diatas diketahui bahwa kedua kelas yang dijadikan sampel dalam penelitian mempunyai $L=$ Maks $\mid F\left(z_{\mathrm{i}}\right)-S\left(z_{\mathrm{i}}\right)<\mathrm{DK}$, maka $\mathrm{L}_{\text {obs }} \notin \mathrm{DK}$ sehingga menyebabkan $\mathrm{H}_{0}$ diterima dan dapat disimpulkan kedua kelas yang dijadikan sampel berdistribusi normal. Tahapan selanjutnya dalah melakukan uji homogenitas pada data kemampuan awal siswa. Uji homogenitas digunakan untuk mengetahui apakah sampel berasal dari populasi yang berdistribusi normal atau tidak, uji yang digunakan adalah uji $F$ dengan tingkat signifikan $\alpha=0,05$ dengan statistik uji $\mathrm{F}=\frac{\mathrm{s}_{1}{ }^{2}}{\mathrm{~s}_{2}{ }^{2}} \sim$ $F\left(n_{1}-1, n_{2}-1\right)$. Dari hasil perhitungan diperoleh nilai $\mathrm{F}=1,56$ dengan $\mathrm{DK}$ $=\{\mathrm{F} \mid \mathrm{F}<0,48$ atau $\mathrm{F}>2.09\}$, maka $F_{\text {obs }}=1,56 \notin D K$ sehingga menyebabkan $\mathrm{H}_{0}$ diterima, maka dapat disimpulkan bahwa variansi kedua sampel homogen.

Hasil uji keseimbangan antara kelas eksperimen dan kelas kontrol dengan uji- $t$ disajikan pada tabel berikut.

Tabel 3. Rangkuman Uji Keseimbangan

\begin{tabular}{|c|c|c|c|c|c|c|}
\hline Kelas & $\bar{X}$ & $N$ & $s$ & $t_{\text {obs }}$ & $t_{\text {tabel }}$ & Kep. Uji \\
\hline Eks & 43,1 & 9 & 30,75 & \multirow{2}{*}{7,249} & 1,960 & $\begin{array}{c}\mathrm{H}_{0} \\
\text { diterima }\end{array}$ \\
\hline Kontrol & 38,6 & 9 & 24,6 & & & \\
\hline
\end{tabular}

$\mathrm{H}_{0}: \mu_{1}=\mu_{2}$ (kemampuan siswa kelas eksperimen dan kelas kontrol sama) dan $\mathrm{H}_{1}: \mu_{1} \neq \mu_{2}$ (kemampuan siswa kelas eksperimen dan kelas kontrol berbeda), dengan $\alpha=0,05$ sehingga $t_{0.025 ; 9}=$ 1,960; DK= $\{t \mid t<-1,960$ atau $t>1,960\}$ dan $t_{o b s}=$ $1,187 \notin \mathrm{DK}$, sehingga $\mathrm{H}_{0}$ diterima. Hasil dari uji keseimbangan dikarenakan $\mathrm{H}_{0}$ diterima maka dapat disimpulkan kemampuan siswa antara kelas eksperiman dan kelas kontrol adalah dalam keadaan yang seimbang.

Tahap selanjutnya adalah memberikan perlakuan yang berbeda pada kelas kontrol dan eksperimen, yaitu pembelajaran e-learning dengan video pembelajaran berbasis aplikasi bandicam dan pada kelompok eksperimen menggunakan pembelajaran e-learning tanpa video pembelajaran berbasis aplikasi bandicam. Postes dalam penelitian ini menggunakan 5 buah soal uraian yang sebelumnya telah diuji validitas dan reliabilitasnya. Uji hipotesis dilakukan dengan uji- $t$ dengan prasyarat uji normalitas dan uji homogenitas pada sampel penelitian. Hasil uji normalitas hasil penelitian terangkum pada tabel berikut.

Tabel 4. Rangkuman uji normalitas hasil penelitian

\begin{tabular}{|c|c|c|c|c|}
\hline Kelas & $N$ & $\begin{array}{c}L=\text { Maks } \mid F\left(z_{\mathrm{i}}\right)- \\
S\left(z_{\mathrm{i}}\right) \mid\end{array}$ & $D K$ & Kep. Uji \\
\hline Eks & 9 & 0,1612 & 0,1618 & $\mathrm{H}_{0}$ diterima \\
\hline Kontrol & 9 & 0,1572 & 0,1591 & $\mathrm{H}_{0}$ diterima \\
\hline
\end{tabular}

Berdasarkan tabel diatas diketahui bahwa kedua $L=$ Maks $\mid F\left(z_{\mathrm{i}}\right)-S\left(z_{\mathrm{i}}\right)<\mathrm{DK}$, sehingga dapat disimpulkan kedua kelompok sampel berdistribusi normal. Selanjutnya uji homogenitas dengan uji $\mathrm{F}$ dengan $\alpha=5 \%$ pada kedua kelompok diperoleh hasil nilai $\mathrm{F}=1,68$ dengan $\mathrm{DK}=\{\mathrm{F} \mid \mathrm{F}<0,48$ atau $\mathrm{F}>2.09\}$, maka $F_{\text {obs }}=1,68 \notin D K$ sehingga menyebabkan $\mathrm{H}_{0}$ diterima dan disimpulkan bahwa kedua sampel homogen.

Tahapan berikutnya adalah melakukan uji hipotesis dengan uji-t. Hasil uji- $t$ dengan tingkat signifikansi $\alpha=5 \%$ terangkum dalam tabel berikut.

Tabel 5. Rangkuman uji hipotesis

\begin{tabular}{|c|c|c|c|c|c|c|}
\hline Kelas & $\bar{X}$ & $N$ & $s$ & $t_{\text {obs }}$ & $t_{\text {tabel }}$ & Ket \\
\hline Eks. & 81,67 & 9 & 9,43 & 1,187 & 1,645 & $\mathrm{H}_{0}$ \\
\hline Kontrol & 62,32 & 9 & 12,25 & & & ditolak \\
\hline
\end{tabular}


Uji hipotesis pada penelitian ini menggunakan $\alpha=5 \%$ sehingga $t_{0.025 ; 9}=1,960 ; \mathrm{DK}=\{t \mid t<-1,960$ atau $t>1,960\}$, dengan $\mathrm{H}_{0}: \mu_{1} \leq \mu_{2}$ (hasil belajar pembelajaran e-learning dengan video pembelajaran berbasis aplikasi bandicam tidak lebih baik daripada hasil belajar pembelajaran e-learning tanpa video pembelajaran berbasis aplikasi bandicam) dan $\mathrm{H}_{1}: \mu_{1}>\mu_{2}$ (hasil belajar pembelajaran e-learning dengan video pembelajaran berbasis aplikasi bandicam lebih baik daripada hasil belajar pembelajaran elearning dengan video pembelajaran berbasis aplikasi bandicam). Dari tabel 5 diketahui bahwa $t_{o b s}=1,187 \notin \mathrm{DK}$, sehingga $\mathrm{H}_{0}$ ditolak. Berdasarkan hasil uji hipotesis dapat simpulkan bahwa hasil belajar pembelajaran e-learning dengan video pembelajaran berbasis aplikasi bandicam lebih baik dari pada hasil belajar pembelajaran e-learning tanpa video pembelajaran berbasis aplikasi bandicam.

Perubahan perlakuan yang dilakukan pada pembelajaran hasil belajar pembelajaran elearning dengan video pembelajaran berbasis aplikasi bandicam ternyata memberikan hasil yang lebih baik dibandingkan dengan pembelajaran e-learning yang tanpa perubahan. Hal ini dikarenakan mahasiswa mampu mengabstraksikan model graf di dalam pikiran mereka. Menurut Dagun (1997: 232) abstraksi merupakan pembentukan konsep dengan cara menganalisa ciri atau sifat benda kemudian menetapkannya sebagai hakikat dari benda tersebut. Pada saat proses pembelajaran mahasiswa lebih mudah memahami titik dan garis dalam graf, hal ini terbukti dari beberapa perntanyaan yang diberikan hampir semuanya dijawab dengan benar.

Video pembelajaran memberikan gambaran kepada mahasiswa mengenai model graf tiga dimensi di dalam pikiran mereka, sehingga proses mengabstraksi graf dari gambar menjadi model matematis menjadi lebih mudah.

\section{PENUTUP}

\section{Simpulan}

Berdasarkan hasil penelitian dan pembahasan maka kesimpulan dari penelitian ini adalah penggunaan video pembelajaran berbasis aplikasi bandicam pada pembelajaran daring mata kuliah teori graf memberikan pemahaman abstraksi mahasiswa yang lebih baik daripada pembelajaran daring mata kuliah teori graf tanpa video pembelajaran berbasis aplikasi bandicam.

\section{Saran}

Saran dari penelitian ini adalah pendidik sekiranya dapat memanfaatkan teknologi informasi, internet, dan komputer untuk menunjang proses pembelajaran, aplikasi bandicam merupakan salah satu software yang bisa dmanfaatkan dalam pembelajaran.

\section{DAFTAR PUSTAKA}

Dagun, Save M. 1997. Kamus Besar Ilmu Pengetahuan. Jakarta: Lembaga Pengkajian Kebudayaan Nusantara.

Ignacio, N.G., Blanco Nieto, L.J. \& Barona, E.G. 2006. The Affective Domain In Mathema Tics Learning. International Electronic Journal of Mathematics Education. Vol. 1 No. 1: 16-32.

Iswaji, Joko. 2001. Geometri Ruang. Yogyakarta: FMIPA-UNY.

Tosin. 2013. Analisis Kesulitan Pemahaman Siswa Terhadap Materi Geometri Dimensi Tiga. Skripsi. Perpustakaan IAIN Syekh Nurjati Ciberon.

Wiryanto. 2014. Level-level Abstraksi dalam Pemecahan Masalah matematika. Jurnal pendidikan Teknik Elektro. Vol. 03 No. 06, hal 572-577.

Nurhasanah, Farida. 2009. Abstraksi dan Alat Peraga Maya Dalam Pembelajaran Matematika. Conference Paper. 
Conference: Konferensi Nasional

Pendidikan Matematika At: Unimed Medan.

Husein, hamdan. 2020. Materi Perkuliahan: Perekaman Video Pembelajaran dengan Bandicam dan Powerpoint. UIN Walisongo Semarang. 